\title{
ENZIMAS TERMOESTÁVEIS: FONTES, PRODUÇÃO E APLICAÇÃO INDUSTRIAL
}

\author{
Eleni Gomes*, Marcelo Andrés Umsza Guez, Natalia Martin e Roberto da Silva \\ Instituto de Biociências, Letras e Ciências Exatas, Universidade Estadual Paulista, R. Cristóvão Colombo, \\ 2265, 15054-000 São José do Rio Preto - SP, Brasil
}

Recebido em 28/9/05; aceito em 24/3/06; publicado na web em 30/8/06

\begin{abstract}
THERMOSTABLE ENZYMES: SOURCES, PRODUCTION AND INDUSTRIAL APPLICATIONS - REVIEW: Living organisms encountered in hostile environments that are characterized by extreme temperatures rely on novel molecular mechanisms to enhance the thermal stability of their proteins, nucleic acids, lipids and cell membranes. Proteins isolated from thermophilic organisms usually exhibit higher intrinsic thermal stabilities than their counterparts isolated from mesophilic organisms. Although the molecular basis of protein thermostability is only partially understood, structural studies have suggested that the factors that may contribute to enhance protein thermostability mainly include hydrophobic packing, enhanced secondary structure propensity, helix dipole stabilization, absence of residues sensitive to oxidation or deamination, and increased electrostatic interactions. Thermostable enzymes such as amylases, xylanases and pectinases isolated from thermophilic organisms are potentially of interest in the optimization of industrial processes due to their enhanced stability. In the present review, an attempt is made to delineate the structural factors that increase enzyme thermostability and to document the research results in the production of these enzymes.
\end{abstract}

Keywords: thermostable enzyme; thermophilic microorganism; thermal adaptation.

\section{INTRODUÇÃO}

Em contraste com outros grupos de organismos vivos, os microrganismos apresentam grande capacidade adaptativa colonizando ambientes nos quais outras formas de vida não seriam viáveis, como os ambientes geotérmicos. A adaptação de um determinado microrganismo à termofilia envolve adaptação da membrana citoplasmática, das proteínas e do DNA às temperaturas acima da faixa mesofílica. Essa adaptação à termofilia tem despertado grande interesse sob pontos de vista biológicos e evolutivos. Porém, foi na biotecnologia que esse interesse foi mais significativo, considerando que os mecanismos de termorresistência das biomoléculas desses microrganismos podem constituir modelos interessantes para a bioengenharia ou ainda, considerando o uso direto das mesmas em bioprocessos. As enzimas termoestáveis já têm sido usadas como ferramenta para a Biologia Molecular (Taq polimerase), como aditivo de detergentes e sabões (proteases e celulases), no processamento industrial do amido ( $\alpha$-amilase, glucose isomerase) e na indústria de polpa e papel (xilanase) e surgem como alternativas de interesse em outros bioprocessos, como o de síntese orgânica (lipases, proteases, oxidorredutases), no setor de diagnóstico, no tratamento de resíduos e na produção de ração animal ${ }^{1,2}$.

As proteínas de microrganismos termófilos apresentam sequiências de aminoácidos, estrutura tridimensional e mecanismos catalíticos idênticos aos de suas similares mesofílicas. A maior termoestabilidade intrínseca observada nessas moléculas tem sido foco de inúmeras teorias e pesquisas, porém, ainda não é completamente entendida. Algumas diferenças na composição de aminoácidos, nos mecanismos de manutenção do enovelamento e da estabilização da estrutura foram constatadas entre enzimas de mesófilos e termófilos ${ }^{3}$, porém, os fatores de pressão seletiva (pressão, $\mathrm{pH}$, temperatura) e as variações filogenéticas devem ser considerados.

Na presente revisão, são abordados os mecanismos de adaptação dos microrganismos ao crescimento em altas temperaturas e

*e-mail: eleni@ibilce.unesp.br aqueles responsáveis pela manutenção da estrutura das proteínas nessas condições. São destacadas, também, a produção e a importância da termoestabilidade de algumas enzimas microbianas, como as amilases, xilanases e pectinases, nos processos industriais.

\section{MICRORGANISMOS TERMÓFILOS}

Uma das mais surpreendentes propriedades dos microrganismos é sua habilidade em adaptar-se a ambientes extremos, nos quais fatores como $\mathrm{pH}$, temperatura, pressão e concentração de sal ultrapassam os valores considerados como padrões para a maioria dos seres vivos ${ }^{4}$. Dentre todos esses fatores, a temperatura é o que mais influencia a função das biomoléculas e a manutenção das estruturas biológicas. De fato, a maioria dos organismos atualmente conhecida pode crescer somente dentro de uma faixa estreita de temperatura. Entretanto, a existência de ambientes geotermicamente estáveis tem permitido a seleção ou a persistência de microrganismos que não apenas resistem, mas também requerem altas temperaturas para sobreviver. Estes organismos são chamados de termófilos (ou termofílicos) e são classificados em ${ }^{5}$ : termófilos (ou termofílicos) moderados que incluem organismos com faixa de crescimento entre um mínimo de $20^{\circ} \mathrm{C}$ e um máximo de $55^{\circ} \mathrm{C}$, sendo as temperaturas ótimas entre 40 e $50{ }^{\circ} \mathrm{C}$. Nesse grupo estão incluídos os procariotos dos Domínios Bacteria e Archaea e os eucariotos (Domínio Eukarya - fungos filamentosos); termófilos extremos que incluem microrganismos capazes de crescer otimamente em temperaturas entre 65 a $85{ }^{\circ} \mathrm{C}$. Esse grupo é representado pelos procariotos dos Domínios Bacteria e Archaea; hipertermófilos, entre os quais estão as Archaea com temperaturas ótimas de crescimento de 85 até $110^{\circ} \mathrm{C}$. Na Figura 1 é apresentada a árvore filogenética, destacando os domínios evolutivos e os filos que os compõem.

Evidências sugerem que organismos hipertermófilos foram as primeiras formas de vida na Terra $^{6}$ e suas proteínas podem, portanto, servir como modelo para o entendimento da evolução das enzimas sob os pontos de vista biológico, químico e físico-químico? ${ }^{7}$.

Embora não se conheça a temperatura máxima na qual a vida é possível, acredita-se que esta não atinja valores muito acima de 110 


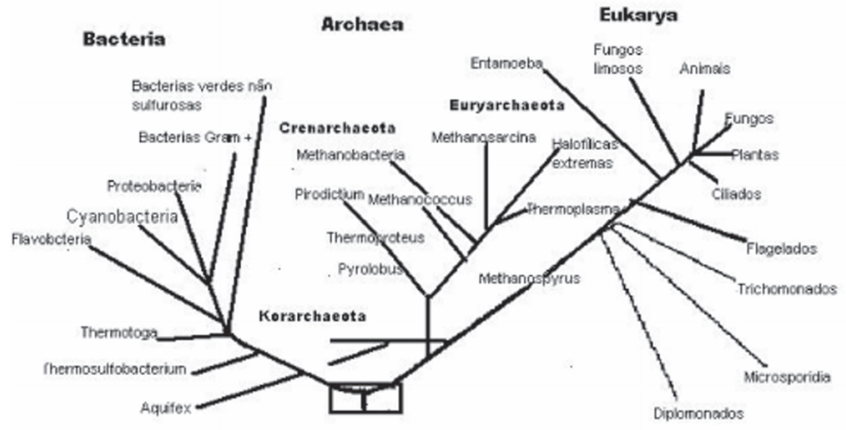

Figura 1. Árvore filogenética dos domínios Archaea, Bactéria e Eukarya e os respectivos filos

${ }^{\circ} \mathrm{C}$, temperatura em que os aminoácidos e outros metabólitos e monômeros celulares são instáveis, embora o ATP entre em hidrólise espontânea somente a $140{ }^{\circ} \mathrm{C}^{8,9}$.

Existem mais de 70 espécies inseridas em 29 gêneros e 10 ordens de hipertermófilos conhecidos, sendo a maioria do Domínio Archaea. Entre os organismos hipertermófilos descritos, o Pirococcus fumari é o que consegue crescer em temperaturas mais elevadas, entre 90 e $113{ }^{\circ} \mathrm{C}^{10}$. No Domínio Bactéria, foram descritas algumas espécies hipertermofílas como Aquiflex pyrophilus, Fervidobacterium pennavorans, Thermotoga marítima, Thermocrinis rubber, Aquiflex profundus e Thermotoga neapolitana ${ }^{11-14}$.

Poucas espécies de Eucariotos conseguem crescer entre 45 e 55 ${ }^{\circ} \mathrm{C}$, sendo classificadas como termofílicas moderadas. Dentre as 50.000 espécies de fungos descritas, somente cerca de 30 crescem em temperaturas entre 40 e $45^{\circ} \mathrm{C}$, embora existam algumas espécies com capacidade de crescer entre 60 e $62{ }^{\circ} \mathrm{C}$. Essa menor tolerância ao calor deve-se mais aos seus complexos sistemas de membrana, que à termoestabilidade das enzimas ou de outros compostos químicos celulares. O primeiro fungo termófilo isolado foi Mucor pusillus, há um século atrás. Em seguida, Hugo Miehe estudou a microflora de pilha de compostagem de resíduos agrícolas, isolando outras espécies de fungos termófilos ${ }^{15}$.

$\mathrm{Na}$ natureza, em ambiente mesofílico, os organismos termófilos moderados desenvolvem-se em processo de compostagem durante a fase de alta temperatura (acima de $40{ }^{\circ} \mathrm{C}$ ), sucedendo a microflora mesofílica ${ }^{15,16}$. Nesse processo, podem ser distinguidas três fases: na primeira, a microbiota mesofílica cresce aceleradamente, assimilando, preferencialmente, as fontes de carbono prontamente assimiláveis e solúveis (açúcares, aminoácidos e ácidos orgânicos) ou polímeros de acesso mais fácil, gerando calor por reações metabólicas exotérmicas e elevando a temperatura para aproximadamente $40{ }^{\circ} \mathrm{C}$. Esse aumento de temperatura inibe o crescimento dos mesófilos e estimula a germinação dos esporos dos fungos e endósporos das bactérias termófilas, iniciando a segunda fase do processo. Nessa etapa, as fontes de carbono mais facilmente assimiláveis já estariam exauridas, restando os polissacarídeos constituintes da biomassa, como celulose, hemicelulose e pectina, cuja degradação requer intensa liberação de enzimas extracelulares. O resultado desse processo é a degradação do material vegetal a polímeros menores e um aumento da temperatura para próximo de $60{ }^{\circ} \mathrm{C}$. A terceira fase do processo caracteriza-se pela inibição do crescimento dos fungos e redução de atividade bioquímica no material, embora as atividades das bactérias extremófilas e hipertermófilas sejam continuadas ${ }^{17}$. Pelo exposto, espera-se que fungos e bactérias termófilos moderados sejam potenciais produtores de enzimas despolimerizantes. Entretanto, alguns fungos termófilos como Thermomyces lanuginosus, Talaromyces duponte e Mucor (Rhizomucor) pusillus não conseguem utilizar a celulose como fonte de C. Porém, a incapacidade de hidrolisar um determinado polímero, como celulose, não significa que o fungo não tenha sistema enzimático para hidrólise de outro polímero. Alguns fungos, como Humicola insolens, não degradam celulose mas são capazes de usar a xilana como fonte de carbono e crescem mais rapidamente sobre esse polímero que em meio com açúcares mais simples. Do mesmo modo, fungos pectinolíticos termófilos nem sempre são bons produtores de enzimas hemicelulolíticas. Por outro lado, os organismos que não despolimerizam a matéria orgânica podem crescer comensalmente, utilizando açúcares liberados por outros organismos ${ }^{18}$.

\section{Adaptação dos microrganismos à termofília}

A adaptação de um determinado microrganismo à termofilia envolve aspectos cruciais, como ajustamento da membrana citoplasmática, das proteínas e do DNA às temperaturas acima da faixa mesofílica.

As diferenças entre as membranas de termófilos e de mesófilos consistem, principalmente, na substituição de ácidos graxos insaturados por ácidos graxos saturados, de modo que a membrana adquira um equilíbrio entre densidade e fluidez, necessário para a manutenção de sua integridade física e funcional em temperaturas elevadas. Os ácidos graxos saturados geram ambiente mais fortemente hidrofóbico que os insaturados, auxiliando na estabilidade da membrana. Essa adaptação ocorre nos Domínios Bactéria e Eukarya (Reino Fungi) ${ }^{19}$. No Domínio Archaea, as membranas apresentam lipídeos formados por ligação éter entre o glicerol e um hidrocarboneto (cadeias hidrofóbicas longas formadas por repetidas unidades do composto contendo cinco $\mathrm{C}$ isopreno). Os lipídeos mais comuns de Archaea são glicerol diéter e diglicerol tetraéter de fitanil $\left(\mathrm{C}_{20}\right)$ e bifitanil $\left(\mathrm{C}_{40}\right)$ (Figura 2). Além disso, a estrutura geral dessas membranas corresponde a uma monocamada lipídica em contraste com o modelo de bicamada formada por ácidos graxos e glicerol das membranas biológicas convencionais. Essa estrutura diferenciada possibilita a estabilização da membrana citoplasmática em temperaturas em torno de $100{ }^{\circ} \mathrm{C}^{20-23}$.

A manutenção da estrutura do DNA é, sem dúvida, um fator imprescindível para a estabilidade de organismos termófilos, prin-
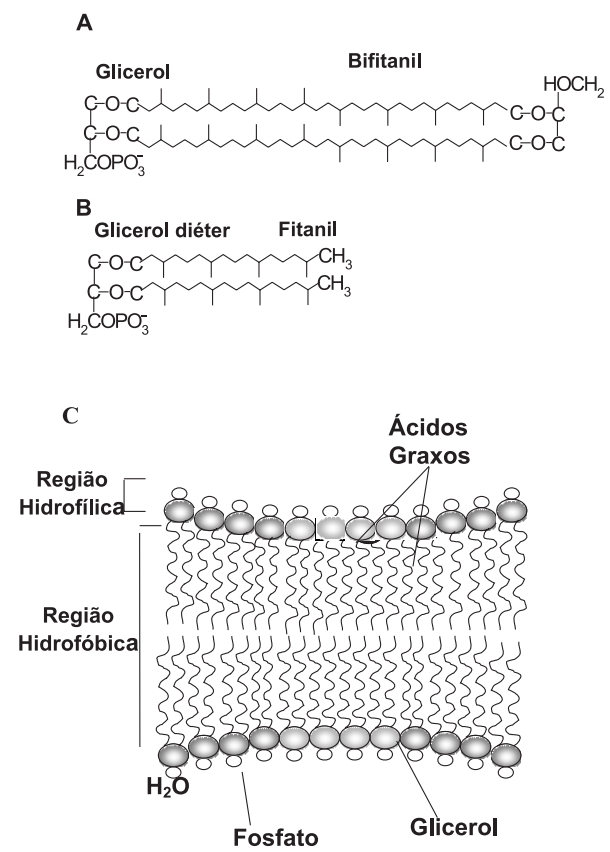

Figura 2. Composição lipídica de membranas de Archaea termofilicas (A e B) e de Bactérias $(C)$ 
cipalmente dos hipertermófilos. No citoplasma desses últimos tem sido detectada grande quantidade de 2,3-difosfoglicerato cíclico de potássio, cuja função é impedir danos químicos na molécula de DNA, como a despurinação que pode ocorrer em altas temperaturas. Ainda, todos os hipertermófilos produzem uma única forma diferenciada de DNA topoisomerase chamada DNA Girase Reversa, a qual introduz superenovelamentos positivos no DNA, em contraste com os superenovelamentos negativos gerados pela DNA Girase convencional. $\mathrm{O}$ superenovelamento positivo promove maior resistência do DNA à desnaturação térmica ${ }^{5,24}$. Outras proteínas também aparecem relacionadas com a termoestabilidade do DNA, como por ex., uma pequena proteína termoestável chamada Sac7d, encontrada em Sulfolobus, que se liga ao sulco menor do DNA aumentando sua temperatura de desnaturação em cerca de $40{ }^{\circ} \mathrm{C}$. Semelhante à Sac7d, existem também as proteínas fortemente básicas, com seqüência homóloga às histonas de Eukarya, chamada "histonas de Archaea", que compactam o DNA em estruturas semelhantes aos nucleossomos de eucariotos mantendo-o em dupla fita mesmo em temperaturas elevadas ${ }^{25,26}$.

Estudos comparativos entre seqüências genômicas de microrganismos mesófilos e termófilos revelaram diferenças na composição de nucleotídeos. Sequiências codificantes de termófilos possuem altos teores de purinas, principalmente adenina (A), sugerindo que esse nucleotídeo exerce função adaptativa de estabilização da estrutura do RNA, além de contribuir para mudanças na frequiência de certos aminoácidos na sequiência protéica. Por outro lado, a preferência por citosina $(\mathrm{C})$ em relação à Timina $(\mathrm{T})$ em certos grupos de códons pode aumentar a estabilidade do pareamento códonanticodon em temperaturas elevadas ${ }^{27}$.

Dentre os fatores que afetam a estabilidade e cinética das proteínas ( $\mathrm{pH}$, detergentes, agentes caotrópicos e calor) o calor é que mais exige modificações das proteínas, dentro do contexto biológico. Essas adaptações têm sido foco de inúmeras pesquisas ${ }^{28}$, visando a compreensão dos mecanismos envolvidos. Enzimas estáveis em temperaturas elevadas são chamadas termozimas e hipertermozimas, contra a terminologia equivalente-mesozimas- para as mais termolábeis.

\section{Fatores da termoestabilidade de enzimas}

A termoestabilidade de uma enzima refere-se tanto à termoestabilidade dinâmica e quanto à estabilidade cinética. A termoestabilidade dinâmica $\left(\mathrm{T}_{m}\right)$ representa $50 \%$ da enzima desdobrada e a termoestabilidade cinética reflete a meia vida $\left(T_{1 / 2}\right)$ da enzima, a uma determinada temperatura. Essa termoestabilidade está diretamente associada ao dobramento da proteína, o qual é estabilizado por equilíbrio entre forças de dobramento e de desdobramento (energia de estabilização da enzima $\Delta G_{\text {stab }}$ ) que é representado por $\Delta G_{\text {stab }}=\Delta H_{\text {stab }}-T$. $\Delta S_{\text {stab }}$, onde $\Delta \mathrm{H}=$ entalpia de estabilização (dobrado) e $\Delta S=$ entropia (desdobrado) ${ }^{28,29}$.

A conformação funcional para termozima e mesozima é a mesma, conforme mostrado pela curva Anhenius linear, sugerindo que as mesmas permanecem inalteradas apesar da diferença de temperatura de atuação de ambas. Entretanto, deve ser destacado que algumas enzimas de hipertermófilos apresentam curva de Anhenius atípica, com bifase, indicando mudança conformacional significativa ${ }^{30}$.

A proteína nativa é mantida por um delicado balanço de forças não covalentes, como pontes de hidrogênio, pareamento de íons, interações hidrofóbicas e força de van der Waals. Com o aumento da temperatura, essas interações são rompidas e a proteína se desdobra $^{31}$. O grau de desdobramento de uma proteína pode ser observado por colorimetria, fluorescência, espectroscopia de discroísmo circular, viscosidade e migração. Algumas proteínas recuperam sua conformação ativa após o resfriamento, porém, para a maioria, a desnaturação é irreversível ${ }^{32}$. As proteínas desenroladas formam estruturas dispersas que podem se agregar. Essa agregação ocorre quando resíduos hidrofóbicos, que normalmente ficam no interior da molécula nativa e são expostos ao solvente, em consequiência do desenrolamento, interagem com outros resíduos hidrofóbicos de outras cadeias desenroladas. Esses agregados precipitam, caracterizando a enzima desnaturada ${ }^{33}$.

Outro fator de desnaturação da proteína é a desamidação da Asparagina (Asn) e da Glutamina (Gln). Proteínas desenroladas tornam-se muito mais susceptíveis à desamidação que as nativas, pois os resíduos mais susceptíveis são expostos. No mecanismo ácido-base geral, o ácido geral (HA) protona o grupo (-NH) da Asn. A base geral $\left(\mathrm{A}^{-}\right.$ou $\left.\mathrm{OH}^{-}\right)$ataca o $\mathrm{C}$ do grupo carbonila do grupo amida ou ativa um outro grupo nucleofílico. O estado de transição é, supostamente, um intermediário oxi-anion tetraédrico (Figura 3). A ordem com que o ácido ou a base ataca depende do $\mathrm{pH}^{34,35}$.

$\mathbf{A}$

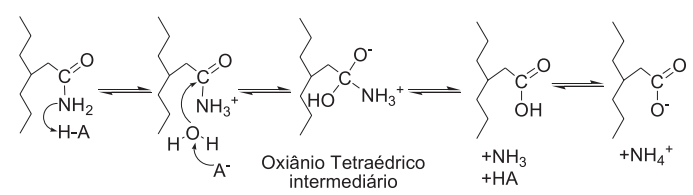

B

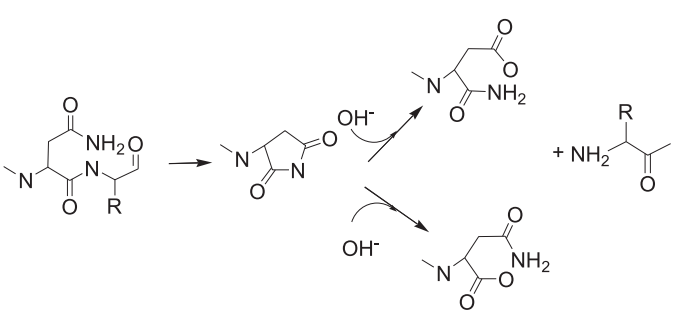

Figura 3. Mecanismos de degradação de proteína. Reação de desamidação por mecanismo geral ácido base (A) e quebra de ligação peptídica (B). Adaptado da ref. 11

A desnaturação das proteínas também é atribuída à hidrólise de ligações peptídicas, a qual ocorre mais freqüentemente no C-terminal lateral do ácido Aspártico (Asp), em ligações entre Asp' $\rightarrow$ Prolina (Pro) a qual tem se mostrado ser a mais lábil das ligações peptídicas. Essa maior labilidade deve-se ao fato do nitrogênio(N) da Pro ser mais básico que o de outros resíduos e o Asp tem uma propensão aumentada para a $\beta$-isomerização quando ligados ao $\mathrm{N}$ da (Pro). Também pode ocorrer clivagem entre as ligações Asn' $\rightarrow$ Xaa (aminoácidos X) por um mecanismo semelhante no $\beta$-aspartil. Nessa reação, o grupo amino do Asp atua como nucleófilo, atacando seu próprio $\mathrm{C}$ da carboxila da cadeia principal (Figura 3). A temperatura que favorece o desenrolamento também aumenta a propensão à quebra das ligações peptídicas ${ }^{36}$.

A $\beta$-eliminação de pontes dissulfeto também é fator de desnaturação de proteínas, sendo mais susceptíveis aquelas com alto teor de aminoácidos sulfurados. A reação de $\beta$-eliminação consiste na destruição das pontes $\mathrm{S}-\mathrm{S}$ em condições alcalinas, produzindo diidroalanina e tiocisteína (Figura 4). A primeira reage como grupo nucleofílico, principalmente grupo amino da Alanina (Ala), e forma lisinoalanina. A ação da segunda não é ainda bem entendida. A $\beta$-eliminação produz tióis livres que podem catalisar permutas de pontes de S-S e desnaturar a proteína ${ }^{11}$.

A oxidação da Cisteína (Cys), geralmente catalisada por cátions, principalmente $\mathrm{Cu}^{+2}$, leva à formação de pontes $\mathrm{S}-\mathrm{S}$ intra e intermolecular. A Cys também pode desencadear trocas de $\mathrm{S}-\mathrm{S}$ levan- 


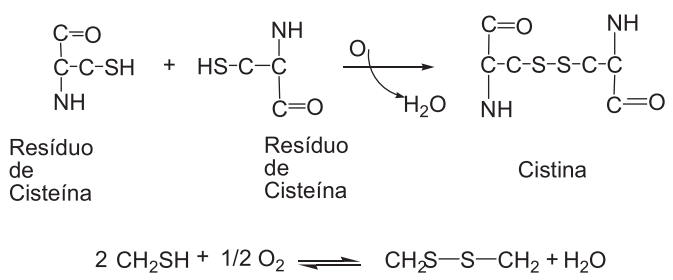

Figura 4. Reação de oxidação e redução da cistina na formação e quebra de pontes dissulfeto na molécula de proteína

do à variação estrutural, como por ex., pontes S-S interunidades ${ }^{37}$.

A exposição de alguns resíduos mais susceptíveis a modificações químicas, decorrente do desenrolamento da molécula de proteína, também pode acelerar outras reações envolvendo outros resíduos de aminoácidos, como oxidação da Metionina (Met) ao seu sulfóxido, racemização de resíduos Asp, mudança da Serina (Ser) para sua forma D, reação da Lisina (Lys) com açúcar redutor (reação de Maillard), autólise de proteases decorrentes de alterações das dobras da estrutura secundária ${ }^{38}$. Os efeitos da temperatura na mudança da estrutura das proteínas estão resumidos na Figura 5.

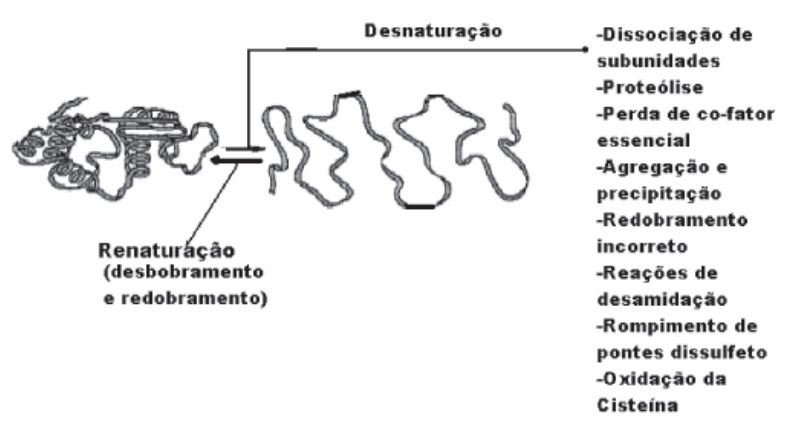

Figura 5. Efeitos da alta temperatura sobre a estrutura da proteína

\section{Características estruturais relacionadas à termoestabilidade de proteínas}

Proteínas de microrganismos termófilos geralmente apresentam maior termoestabilidade intrínseca que sua equivalente mesofílica, embora mantenham a estrutura básica particular da família a que pertencem. Embora o mecanismo molecular da termoestabilização tenha sido foco de inúmeras teorias e pesquisas, ainda não é completamente entendido. Entretanto, algumas diferenças na sequiência, estrutura, função, propriedades dinâmicas e termodinâmicas foram constatadas entre enzimas de psicrófilos, mesófilos e termófilos ${ }^{3}$. Deve ser destacado, porém, que as diferenças observadas nas seqüências das proteínas nem sempre podem ser relacionadas com termoestabilidade, considerando-se que uma combinação de fatores de pressão seletiva atuaram sobre as proteínas por milhões de anos (pressão, $\mathrm{pH}$, temperatura), além das mutações que se acumularam. Dessa forma, para elucidar o mecanismo adaptativo é importante distinguir o comportamento da enzima que é ditado pela biologia, daquele que é ditado pela físico-química (termoestabilidade e propriedades catalíticas).

Durante o curso da evolução, as enzimas foram ajustando suas interações estabilizadoras, de modo a otimizarem o balanço entre rigidez (para a estabilidade) e flexibilidade (para atividade) ${ }^{7}$. Para que uma proteína de psicrofílico tenha eficiência catalítica, a 10 ${ }^{\circ} \mathrm{C}$, comparável a dos mesófilos, a $37{ }^{\circ} \mathrm{C}$, deve exibir, naquela temperatura, um movimento térmico similar ao da mesofílica. Quando essa enzima de psicrofílico é exposta a $37^{\circ} \mathrm{C}$, o movimento térmico torna-se tão acelerado que pode levar à perda de sua estrutura nativa (desdobramento) (Figura 6). Ao contrário, quando a mesozima é resfriada a $10{ }^{\circ} \mathrm{C}$, sua flutuação térmica é reduzida, diminuindo a mobilidade conformacional do sítio catalítico e, conseqüentemente, ocorre uma redução da sua eficiência de catálise ${ }^{39}$. A elevada rigidez intrínseca da proteína termofílica, decorrente da estabilidade do enovelamento, requer alta temperatura de atividade (maior que $40{ }^{\circ} \mathrm{C}$ ) para promover o movimento térmico e o aumento da flexibilidade essencial para a atividade catalítica, ou seja, a adaptação da proteína às temperaturas extremas parece ser resultado de um equilíbrio entre o aumento da rigidez responsável pela estabilidade térmica e a flexibilidade requerida para exercer sua função fisiológica ${ }^{40}$. Inúmeros trabalhos têm evidenciado que a termotolerância das proteínas deve-se, principalmente, a esse aumento da rigidez da molécula ${ }^{39,41,42}$, embora enzimas excepcionalmente flexíveis tenham sido isoladas de Archaea hipertermofílicas ${ }^{43}$.

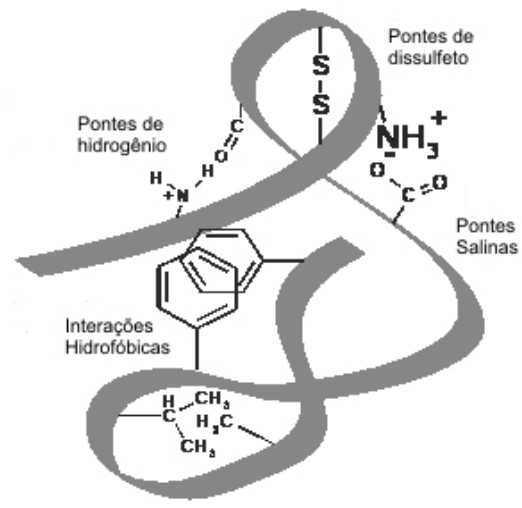

Figura 6. Mecanismos de estabilização da estrutura da proteína

Duas estratégias evolutivas parecem definir a termoestabilidade: fatores intrínsecos ou diretamente associados à estrutura da molécula, levando à rigidez e ao dobramento e, fatores extrínsecos, que ajudam a estabilizar as proteínas em um determinado meio, como alguns solutos, ligantes, chaperonas moleculares e o próprio substrato ${ }^{44}$.

Os fatores intrínsecos que contribuem para a rigidez das proteínas estão relacionados com as estruturas primárias e secundárias das mesmas.

O chamado "efeito hidrofóbico" é o principal mecanismo de termoestabilidade intrínseca da proteína e direciona o enovelamento, que resulta na estrutura nativa da molécula e diminui sua tendência ao desdobramento. Essa conclusão, segundo Scandurra et al. ${ }^{36}$, foi baseada nas seguintes observações: solventes polares desnaturam proteínas termoestáveis; resíduos hidrofóbicos são "seqüestrados" para o interior da molécula, evitando o contato com a água e, resíduos hidrofóbicos das proteínas termoestáveis são mais conservados que os hidrofílicos.

Embora as proteínas de mesófilos tenham uma estabilidade básica dada pelo "core" hidrofóbico, que é a região mais conservada da molécula, a diferença entre estas e as termozimas é a hidrofobicidade; nessas últimas, aparece também nas regiões menos conservadas, formando núcleos altamente hidrofóbicos ${ }^{45}$. O efeito hidrofóbico faz com que as substâncias apolares minimizem seus contatos com a água. A agregação das cadeias apolares dos aminoácidos no interior de uma proteína favorece o aumento da entropia de dobramento da molécula, pois evita a formação de "gaiolas" ordenadas de moléculas de água em torno dos grupos hidrofóbicos. Quanto maior a hidropatia (tendências hidrofóbicas e hidrofílicas combinadas de cada aminoácido) maior a tendência do 
aminoácido ocupar o interior da proteína. Os aminoácidos mais hidrofóbicos são Isoleucina (Ile), Valina (Val), Leucina (Leu), Fenilalanina (Phe), Cys e Met. A Arginina (Arg) é o aminoácido mais hidrofílico. A maioria das termozimas descrita apresenta altos teores de aminoácidos hidrofóbicos e com resíduos aromáticos ${ }^{38}$. Foi comprovado que existem diferenças entre proteínas de mesófilos, termófilos moderados e hipertermófilos quanto ao número de cavidades interiores das moléculas ( $\mathrm{Cav} \mathrm{N})$, volume total $(\mathrm{Cav} \mathrm{V})$ e área de superfície total (Cav A), com valores significativamente menores nesses últimos, embora as diferenças não tenham sido significativas entre proteínas dos dois primeiros grupos ${ }^{46}$.

Além do efeito hidrofóbico, o enovelamento da proteína pode tornar-se mais estável a elevadas temperaturas por modificações na composição de aminoácidos da sequiência primária da molécula e outros fatores, os quais estabilizam a estrutura secundária ( $\alpha$-hélice). Com relação à composição de aminoácidos da sequiência primária, destacam-se: i) substituição da Glicina (Gly): a Gly, na molécula de proteína, é o resíduo que tem a maior entropia conformacional. No processo de dobramento, requer mais energia para restringir sua conformação. Por outro lado, a Ala é o resíduo melhor formador de hélice. Portanto, maior proporção de Ala e menor proporção de Gly permitem maior estabilidade da hélice ${ }^{45,47}$; ii) aumento do teor de Pro: esse aminoácido, com seu anel pirrolidínico, é capaz de adotar apenas poucas configurações e diminui a entropia de desenrolamento, estabilizando a proteína. Portanto, altos teores de Pro aumentam a termoestabilidade ${ }^{48,49}$; iii) redução de resíduos $\beta$-ramificados: resíduos de Val, Ile e Tirosina (Tyr) não são muito tolerantes à hélice em função das ramificações do $\mathrm{C} \beta$. Destaquese, no entanto, que a Ile e Val são aminoácidos com altas hidropatias e aparecem com alta freqüência nos núcleos hidrofóbicos das termozimas $^{11}$; iv) redução de resíduos polares não carregados e aumento dos resíduos carregados: resíduos carregados estabelecem pontes de sais na superfície da molécula aumentando a termoestabilidade $^{50}$. Entretanto, proteínas moderadamente termoestáveis tendem a apresentar maior quantidade de resíduos polares expostos na superfície que as proteínas hiper-termoestáveis ${ }^{46}$; v) substituição da Lys por Arg: entre os aminoácidos carregados positivamente, a Arg é mais adaptada à termofilia, visto que o grupo guanidina tem uma reatividade química reduzida devido ao seu alto $p K a$ e sua ressonância. $\mathrm{O}$ grupo guanidina promove maior área de superfície para interações entre cargas (interações não covalentes) que o grupo amino da Lys. Por ter cadeia lateral com menor quantidade de grupos metileno que a Lys, a Arg tem um potencial menor para desenvolvimento de contato desfavorável com o solvente. A menor relação Arg/Lys nas proteínas termoestáveis pode indicar que o aumento da Arg seria um mecanismo de adaptação à termofilia, embora esse não seja um padrão para todas as termozimas ${ }^{6,51}$; vi) redução do teor de Asp: esse aminoácido é mais susceptível à reação de desamidação decorrente da exposição do resíduo no desdobramento térmico. Quando a enzima termoestável apresenta alto teor desse resíduo, o mesmo encontra-se em localização e em conformação não susceptíveis à desamidação ${ }^{30}$; vii) posicionamento da Cys em termófilos aeróbicos: esse resíduo é susceptível à oxidação quando exposto a solvente em condições oxidativas. Por outro lado, exerce função importante na estabilização da estrutura da proteína, através das pontes S-S. Em função disso, em termófilos aeróbios, a Cys aparece envolvida em interações estabilizadas específicas (pontes S-S ou ligada a metal) e/ou são inacessíveis ao solvente ${ }^{52}$.

As estruturas secundárias de proteínas termoestáveis são estabilizadas pelos mesmos mecanismos das mesofílicas. Porém, os conteúdos de $\alpha$-hélice e de folha $\beta$-pregueada são maiores e a fração de regiões irregulares é menos freqüente em proteínas de termófilos que em proteínas de mesófilos. A estrutura $\alpha$-hélice foi mais freqüentemente observada em proteínas de organismos moderadamente termófilos enquanto a folha $\beta$-pregueada foi maior em hipertermófilos ${ }^{46}$.

Outras características específicas relacionadas com a termoestabilização de proteínas têm sido amplamente discutidas. Revisões detalhadas podem ser encontradas em Vieille e Zeikus ${ }^{11}$ e Fágáin ${ }^{39}$. Uma síntese é apresentada a seguir: i) pontes dissulfeto: as pontes dissulfeto estabilizam a proteína por reduzirem a entropia do estado desenrolado da proteína. Em função da susceptibilidade à oxidação da Cys, a $100{ }^{\circ} \mathrm{C}$, como mencionado anteriormente, supõe-se que esta seja a temperatura limite da termorresistência decorrente de estabilização por S-S. Por outro lado, as enzimas de hipertermófilos, que atuam em temperaturas acima de $100{ }^{\circ} \mathrm{C}$, podem ter $\mathrm{S}-\mathrm{S}$ em regiões inacessíveis ao solvente ${ }^{43}$; ii) pontes de hidrogênio: na $\alpha$-hélice, as pontes de hidrogênio da cadeia principal estão arranjadas de forma que a ligação peptídica $\mathrm{C}=\mathrm{O}$ do enésimo resíduo aponta, ao longo do eixo da hélice, na direção do grupo peptídico $\mathrm{N}-\mathrm{H}$ do resíduo $(n+4)$. Isso resulta em pontes de hidrogênio fortes que têm distância $\mathrm{N} \bullet \bullet O \mathrm{O}$ quase

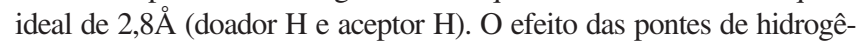
nio na termoestabilização de proteínas tem sido controverso. Embora tenha sido indicado por vários autores como fator de termorresistência ${ }^{53-}$ ${ }^{55}$, de acordo com dados de Szilágyi e Závodszky ${ }^{46}$ praticamente não existem diferenças no número de pontes de hidrogênio entre uma série de proteínas de mesófilos e de termófilos analisadas. Por outro lado, tem sido demonstrada uma forte correlação entre termoestabilidade e o número de ligações $\mathrm{H}$ neutro carregadas, por ex., um átomo da cadeia lateral de um resíduo carregado e outro átomo de cadeia principal ou lateral de resíduo neutro, visto que esse tipo de ligação é termodinamicamente mais estável ${ }^{39}$; iii) pareamento de íons: aparecem em pequenos números na proteína, não são conservados e não direcionam o dobramento da molécula. Esses pareamentos formam uma rede que cruza a superfície da proteína e as interfaces das subunidades. Alguns autores sugerem que a interação eletrostática é importante para a termoestabilidade, visto que as diferenças entre as forças eletrostáticas dos pareamentos de íons tendem a aumentar com a temperatura de crescimento do organismo produtor das proteínas, sendo significativamente maiores em hipertermófilos que em termófilos moderados ${ }^{56}$. Enzimas estabilizadas por interações iônicas, como a metilaminopeptidase de Pirococus furiosus, apresentam redução da estabilidade em $\mathrm{pH}$ ácido, quando os resíduos acídicos estão protonados desfavorecendo a ligação iônica. Tais moléculas também sofrem a ação de altas concentrações de sal que desestabilizam o pareamento iônico ${ }^{57}$. Foi descrito por Lee et al..$^{58}$ que a remoção de resíduos carregados da proteína ribossomal L30e de microrganismo termófilo, por meio de mutação, desestabilizou a proteína sugerindo a desorganização de uma favorável atração eletrostática exercida por esses resíduos; iv) encurtamento do N e C terminais e ancoramento da terminação livre: os "loops" de termozimas são encurtados e/ou melhor ancorados que o resto da proteína. O ancoramento do "loop" é feito por pareamento de íons, pontes de hidrogênio ou por interações hidrofóbicas. A estabilização do $\mathrm{C}$ e $\mathrm{N}$ terminais envolve mecanismos semelhantes aos do "loop" 59,60 ; v) estabilização por ligação com metal: os metais são conhecidos há longo tempo como capazes de estabilizar proteínas. As xiloses isomerases estão ligadas a dois íons metálicos $\left(\mathrm{Co}^{2+}, \mathrm{Mg}^{2+}\right.$ ou $\left.\mathrm{Mn}^{2+}\right)$. Um cátion está diretamente envolvido na catálise e outro na estrutura principal. Os dois metais ligantes têm, portanto, diferentes especificidades e suas exclusões afetam a atividade enzimática, especificidade pelo substrato e termoestabilidade. Várias $\alpha$-amilases termofílicas requerem $\mathrm{Ca}^{2+}$ para sua função e estabilização. Os sítios catalíticos dessas enzimas estão localizados em uma fenda entre dois domínios (um barril $\alpha / \beta$ e um grande "loop") e íons $\mathrm{Ca}^{2+}$ aparecem coordenados por ligantes entre esses domínios ${ }^{61}$. Algumas termozimas possuem metais que não estão presentes em sua homóloga mesofílica, 
como fenoxidina de Sulfolobus sp que contém $\mathrm{Zn}^{2+}$ e serina protease de Thermoactinomyces vulgaris, que contém $\mathrm{Ca}^{2+}$, sugerindo que a aquisição do metal foi fator de adaptação à termoestabilidade ${ }^{62,63}$. A maior estabilidade ao calor apresentada pela enzima L-arabinose isomerase de termófilo, comparada com sua equivalente mesofílica, tem sido atribuída à interação com íons metais divalentes, como $\mathrm{Mn}^{2+}$, os quais são responsáveis pela estabilização da estrutura e oligomerização da proteína ${ }^{58}$; vi) modificação pós-tradução: a glicosilação das proteínas é fator importante na termoestabilidade. Muitas termozimas de eucariotos e procariotos são glicosiladas, embora poucos exemplos em hipertermófilos tenham sido descritos. A glicosilação aumenta a termoestabilidade sem afetar as dobras e a conformação da proteína ${ }^{64,65}$. Foi observado que a glicação, fenômeno que ocorre em proteínas glicosiladas submetidas a altas temperaturas, é também um fator de aumento da termorresistência das moléculas ${ }^{65}$.

Entre os fatores extrínsecos de termoestabilização, destacam-se os solutos, proteínas ligantes, chaperonas moleculares (chaperoninas), sais, coenzimas, ativadores, poliaminas e o próprio substrato. Esse tipo de estabilização é mais comum para enzimas intracelulares ${ }^{66}$.

Os sais inorgânicos ajudam na estabilidade da enzima por exercerem efeitos específico, quando o íon do sal interage com a proteína na maneira conformacional, e geral, relacionado com a redução da atividade de água. Algumas termozimas de metanogênicos são estabilizadas por $\mathrm{K}^{+}, \mathrm{NH}_{4}^{+}, \mathrm{SO}_{4}^{2-}$ e $\mathrm{HPO}_{4}^{2-50,67,68}$. Enzimas citoplasmáticas estabilizadas por sais, requerem um ambiente celular com elevadas concentrações dos mesmos. Essas enzimas apresentam ainda, duas características importantes: redução das hidrofobicidades da superfície e das interfaces das subunidades e presença de resíduos com carga negativa na superfície do tetrâmero ${ }^{1}$ (estrutura quaternária).

Certos solutos como fosfato de di-inositol, fostato de di-glicerol e monosilglicerato são produzidos em quantidades significativas em termófilos e estabilizam proteínas citoplasmáticas contra a desnaturação térmica ${ }^{25}$.

Tem sido descrita, ainda, a estabilização das enzimas pelo próprio substrato e pelo aumento da pressão. O aumento da pressão tende a reduzir o volume da proteína estabilizada por interações hidrofóbicas ${ }^{19}$.

Outro fator de estabilização são as chaperoninas. Por algum tempo confundidas com proteínas de choque térmico (Hsp), as chaperoninas são chaperonas moleculares e têm como função a restauração de proteínas parcialmente desnaturadas pelo calor.

As "chaperonas moleculares" são um grupo de proteínas intracelulares, cuja família mais conhecida corresponde ao sistema Hsp 70 (DnaK em Escherichia coli) e suas co-chaperonas Hsp40 (DnaJ em E. coli) e GrpE ${ }^{69}$. Essas proteínas exercem importantes funções promovem o direcionamento adequado do dobramento das proteínas, através da ligação com os polipeptídeos recém sintetizados, auxiliando seu enovelamento e evitando associações impróprias, as quais poderiam levar a um arranjo inadequado da proteína; previnem a agregação induzida por diferentes tipos de estresses; realizam o transporte de proteínas por membranas e para degradação protéica; atuam na estabilização de fatores de transcrição celular, entre outras ${ }^{70,71}$. As chaperonas permitem, ainda, que proteínas dobradas de maneira imprópria sejam reorganizadas em sua conformação nativa ${ }^{72}$. Essas proteínas são ubíquas, podendo ser encontradas em procariotos, eucariotos, plantas e mamíferos.

As chaperoninas podem ser expressadas sob estresse decorrente do aumento de temperatura, permitindo uma adaptação para a preservação de suas enzimas essenciais. Em Pyrodictium, uma Archaea hipertermofílica, a principal chaperonina chama-se termossomo, que atua mantendo as demais proteínas apropriadamente dobradas e funcionais, mesmo nas elevadas temperaturas de crescimento do organismo (em torno de $\left.110{ }^{\circ} \mathrm{C}\right)^{25}$.

\section{MICRORGANIMOS TERMÓFILOS E PRODUÇÃO DE ENZIMAS TERMOESTÁVEIS DE IMPORTÂNCIA INDUSTRIAL}

As enzimas termoestáveis, de maneira geral, apresentam vantagens para a aplicação na indústria, visto que processos biotecnológicos conduzidos em elevadas temperaturas têm o risco de contaminação por microrganismos mesófilos, que são a maioria em um ambiente industrial, significativamente reduzido $^{73}$. Por outro lado, as temperaturas mais elevadas favorecem a solubilidade de substratos e produtos, e aumentam as taxas de reação por redução da viscosidade e por aumento do coeficiente de difusão dos substratos. Ainda, as enzimas extracelulares constituem importante modelo para entendimento dos mecanismos de termoestabilidade e de atividade em altas temperaturas, os quais são usados nos processos de engenharia de proteínas ${ }^{9,74}$.

Outra característica das enzimas termoestáveis é sua maior resistência à ação de proteases, uma vez que, quanto mais rígida for a molécula, menos expõe seu sítio de proteólise ${ }^{75}$. A maior resistência à desnaturação por alguns solventes orgânicos também tem sido relatada como uma propriedade das proteínas termoestáveis ${ }^{76}$.

\section{Amilases termoestáveis}

A maioria dos processamentos industriais do amido envolve a hidrólise desse polímero. Os chamados "hidrolisados de amido" englobam todos os produtos resultantes do fracionamento do amido, independentemente do catalisador ou do grau de fracionamento. São incluídos nesta denominação diferentes tipos de produtos, como xaropes de glicose, maltose, frutose, maltotetrose, dextrinas e ciclodextrinas ${ }^{77}$. A composição de um hidrolisado que se deseja obter é definida em função do direcionamento da aplicação do mesmo. Cada tipo de xarope requer, portanto, diferentes combinações de enzimas amilolíticas.

Durante muito tempo, o amido foi hidrolisado quimicamente, por ação de ácidos. Esse processo, no entanto, gerava subprodutos indesejáveis, como compostos coloridos ou de "flavor", além de dificultar o controle dos teores dos produtos finais. Nos últimos 30 anos, as amilases substituíram o tratamento ácido.

O processamento enzimático do amido ocorre em altas temperaturas e envolve dois passos importantes, a liquefação e a sacarificação. O fluxograma da Figura 7 resume as etapas da hidrólise enzimática do amido na produção industrial de xaropes. A $\alpha$-amilase termoestável de Bacillus licheniformis ou de Bacillus stearothermophilus hidrolisa parcialmente as ligações $\alpha-1,4$, liberando maltodextrinas, com redução acentuada da viscosidade. Após a liquefação, o pH é ajustado a 4,2-5,0 e a temperatura baixada para $55-60{ }^{\circ} \mathrm{C}$ seguindo-se a etapa de sacarificação, na qual o amido liquefeito é convertido em sacarídeos de baixo peso molecular. Xaropes contendo 95-96\% de glicose são produzidos usando-se, nessa segunda etapa, uma mistura de pululanase e glucoamilase de Aspergillus niger ou de Aspergillus oryzae, enquanto que xaropes com $80-85 \%$ de maltose são produzidos usando pululanase e $\beta$-amilase de Bacillus polymyxa ${ }^{78}$.

As condições de pH e temperatura para as fases de liquefação e sacarificação foram definidas de modo a evitar subprodutos indesejáveis e, principalmente, levando em consideração condições ótimas de atividade e de estabilidade das enzimas. A etapa crítica do processo é a de sacarificação, a qual usa enzimas de mesófilos e, portanto, com menor termoestabilidade, requerendo o resfriamento do material e controle para que a temperatura não ultrapasse $60^{\circ} \mathrm{C}$. Enzimas sacarificantes mais termoestáveis são desejáveis nesse processo, pois evitariam o passo de resfriamento e, conseqüentemente, levariam à redução de custos. Dessa forma, pesquisas com 


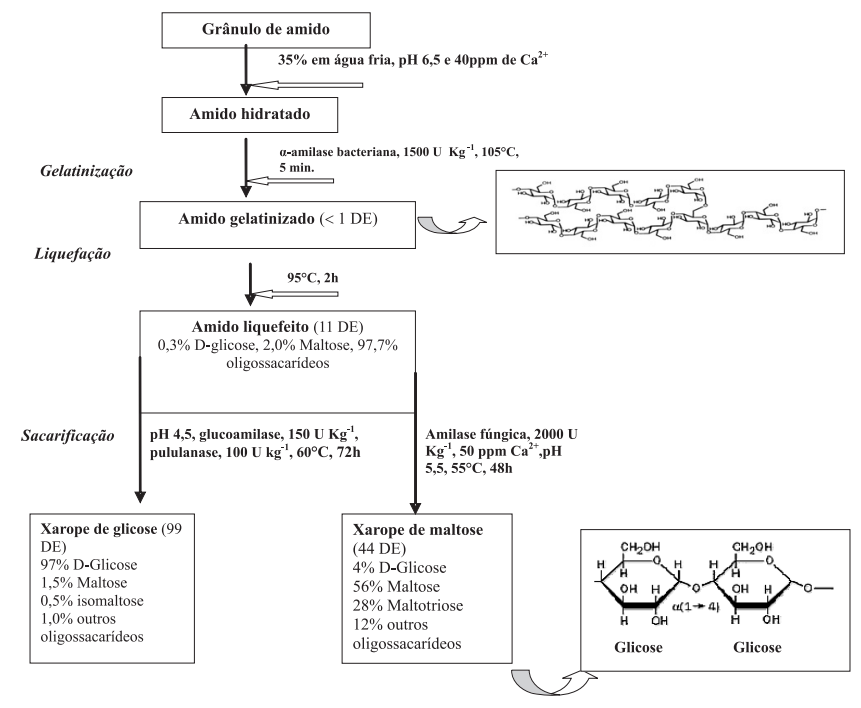

Figura 7. Fluxograma da hidrólise enzimática do amido na produção industrial de xaropes

termófilos, visando a produção de glucoamilases e pululanases mais termoestáveis, são necessárias ${ }^{3,79}$.

Glucoamilases de bactérias termofílicas, como Clostridium thermosulfuricum e Clostridium thermosacarolyticum, que apresentam atividade ótima a $70{ }^{\circ} \mathrm{C}$ por $7 \mathrm{~h}$, foram descritas, além da pululanase de Bacillus flavocaldarius e da CGTase de Bacillus sp subgrupo alcalophilus que são otimamente ativas entre $75-85{ }^{\circ} \mathrm{C}^{80-83}$.

Nas últimas décadas, foi realizada muita pesquisa sobre a produção de amilases pelos hipertermófilos. Thermococcus agregans $e$ Pirococccus furiosus produzem pululanases que atuam a 100 e $105{ }^{\circ} \mathrm{C}$, respectivamente ${ }^{84}$; Thermoanaerobacterium thermosaccharolyticum $\mathrm{e}$ Sulfolobus solfataricus produzem glucoamilases que atuam a 75 e $90{ }^{\circ} \mathrm{C}$, respectivamente ${ }^{85}$ e, Thermotoga marítima produze $\beta$-amilase com atividade ótima a $90{ }^{\circ} \mathrm{C}^{61,86}$. Entretanto, entre as $\alpha$-amilases estão as maiores temperaturas de atuação enzimática encontradas, como as de Thermococcus profundus, Pyrococcus woesi e Pirococcus furiosus ${ }^{87,88}$. A $\alpha$-amilase produzida por Pirococcus furiosus apresentou-se cataliticamente ativa a $140{ }^{\circ} \mathrm{C}$, com meia vida a $120^{\circ} \mathrm{C}$ por $2 \mathrm{~h}^{89}$.

$\mathrm{O}$ uso direto dos organismos hipertermófilos para produção das enzimas tem se mostrado inviável, em função das dificuldades de cultivos dos mesmos e baixa expressão dos genes envolvidos. A alternativa que se busca é a expressão desses genes em organismos mais adaptados a processos fermentativos industriais, como Escherichia coli ou leveduras ${ }^{11,90}$.

Os fungos, embora sejam organismos eucarióticos e, portanto, com termofilia moderada, são também bons produtores de amilases termoestáveis. Um fato interessante, é que, mesmo entre os mesófilos, que crescem entre 28 e $32{ }^{\circ} \mathrm{C}$, é possível encontrar enzimas que atuam em temperaturas até $30{ }^{\circ} \mathrm{C}$ acima da temperatura máxima de crescimento do organismo produtor, como a glucoamilase de Neosartorya fischeri, que atua a $60{ }^{\circ} \mathrm{C}^{91}$, a glucoamilase de Aspergillus fumigatus, com atuação a $60{ }^{\circ} \mathrm{C}^{92}$, a amilase de Mucor sp, que atua a $60{ }^{\circ} \mathrm{C}^{93}$, a glucoamilase de Monascus sp $\mathrm{KB} 9$ que atua a $65{ }^{\circ} \mathrm{C}^{94}$, glucoamilase de Acremonium sp que atua a $55^{\circ} \mathrm{C}$, mas é estável a $60{ }^{\circ} \mathrm{C}^{95}$, além das muito conhecidas glucoamilases de Aspergillus niger com atuação a $60{ }^{\circ} \mathrm{C}^{96}$.

$\mathrm{O}$ fungo termófilo mais estudado como produtor de enzimas extracelulares, o Thermoascus aurantiacus, teve sua produção de amilase descrita em 1970, por Jayachandran e Ramabadran ${ }^{97}$. A partir daí, vários outros fungos termófilos e termotolerantes têm sido estudados: Mucor pusillus, que produziu $\alpha$-amilase com atividade a $70{ }^{\circ} \mathrm{C}^{98}$,
Scytalidium thermophilum, com uma glucoamilase e uma $\alpha$-amilase com ação a $65^{\circ} \mathrm{C}^{99,100} \mathrm{e}$ Streptosporangium sp, Talaromyces emersoni e Aspergillus flavus A1.1, cujas glucoamilases atuam a $70{ }^{\circ} \mathrm{C}^{101-103}$.

O fungo Humicola lanuginosa, hoje identificado como Thermomyces lanuginosus ${ }^{17}$, é um excelente produtor de glucoamilase que apresenta estabilidade a $60{ }^{\circ} \mathrm{C}^{103-105} \mathrm{e}$ de $\alpha$-amilase, também termoestáve ${ }^{97,106}$. Outras linhagens de Thermomyces lanuginosus como ATCC 28083, T. lanuginosus ATCC 34626, T. lanuginosus ATTC 44008 e T. lanuginosus A 13.37 produziram $\alpha-$ amilase e glucoamilase com atuação a $70{ }^{\circ} \mathrm{C}^{103,107}$. A $\alpha$-amilase produzida pela linhagem Thermomyces lanuginosus ATCC 34626 apresentou meia vida a $60{ }^{\circ} \mathrm{C}$ por $1 \mathrm{dia}^{108}$.

Observa-se que não existe diferença muito pronunciada entre as termoestabilidades e as temperaturas de atividade ótima das amilases produzidas por fungos termófilos e alguns mesófilos. Essa questão é muito interessante e requer estudos de seqüenciamento das proteínas similares purificadas a partir dos dois grupos.

Outros tipos de enzimas amilolíticas, como a ciclomaltodextrina gluconosiltranferase (CGTase), que convertem oligodextrinas em ciclodextrinas, a $\alpha$-glucosidase, que libera glicose a partir de dextrinas curtas e a pululanase, que atua sobre o pululano, também apresentam formas termoestáveies ${ }^{109,110}$. Espécies do gênero Themococcus produzem CGTases com atuação a 90 e $100{ }^{\circ} \mathrm{C}$ e estabilidade a $105^{\circ} \mathrm{C}^{111}$.

\section{Pectinases termoestáveis}

As pectinases são um importante grupo de enzimas capazes de hidrolisar a pectina presente na lamela média e parede primária das células vegetais (Figura 8).O uso de temperaturas elevadas durante o processamento de suco e outros produtos vegetais são etapas importantes dos processos industriais e têm diversas finalidades.

$\mathrm{Na}$ maceração da uva para extração de suco, a incubação a 60-65 ${ }^{\circ} \mathrm{C}$ promove a plasmólise da membrana e rupturas na parede celular do fruto, facilitando a liberação do líquido e de antocianinas responsáveis pela cor do suco. Na extração de sucos de uva para produção de vinhos, a fruta macerada é tratada a $80{ }^{\circ} \mathrm{C}$ para, além de facilitar a maceração, desnaturar oxidases que causam perda da cor do vinho durante a estocagem. Na extração do "pulp wash", a polpa da laranja (mistura de polpa e semente), resultante do peneiramento do suco de primeira, é aquecida a $90{ }^{\circ} \mathrm{C}$ para desnaturar a pectina esterase da fruta, que causa problemas de coagulação da pectina. Além das funções citadas, o tratamento térmico ainda tem por finalidade a pasteurização dos sucos e mostos, visando a redução da microbiota contaminante, principalmente de leveduras. Em todos esses processos citados, o material submetido ao aquecimento precisa ser posteriormente resfriado a $50{ }^{\circ} \mathrm{C}$ para tratamento com pectinases comerciais, as quais são termolábeis ${ }^{112}$. O uso de pectinases termoestáveis evitaria a etapa de resfriamento, reduzindo tempo e custo dos processos.

A produção de poligalacturonase termoestável pelo fungo termófilo Sporotrichum thermophile Apinis, foi relatada por Kaur et al. ${ }^{113}$, a qual, aplicada na extração de sucos de banana, uva e maçã, a $55^{\circ} \mathrm{C}$, proporcionou considerável aumento no rendimento.

Pectinases termoestáveis seriam muito úteis também na degradação de pectina de resíduos de indústria de processamento de material vegetal, reduzindo a Demanda Bioquímica de Oxigênio (DBO) e a Demanda Química de Oxigênio (DQO) dos mesmos, e no processamento e desengomagem de fibras têxteis, nos quais a temperatura mais elevada reduziria a presença de contaminantes mesófilos ${ }^{114}$.

A extração de açúcar de beterraba, responsável por $29 \%$ da produção mundial de açúcar, requer a despectinização para aumento do rendimento, visto que mais de $30 \%$ do peso seco da beterraba corresponde à pectina. Industrialmente, essa extração é feita em temperaturas de aproximadamente $70{ }^{\circ} \mathrm{C}$ e, dessa forma, uma 


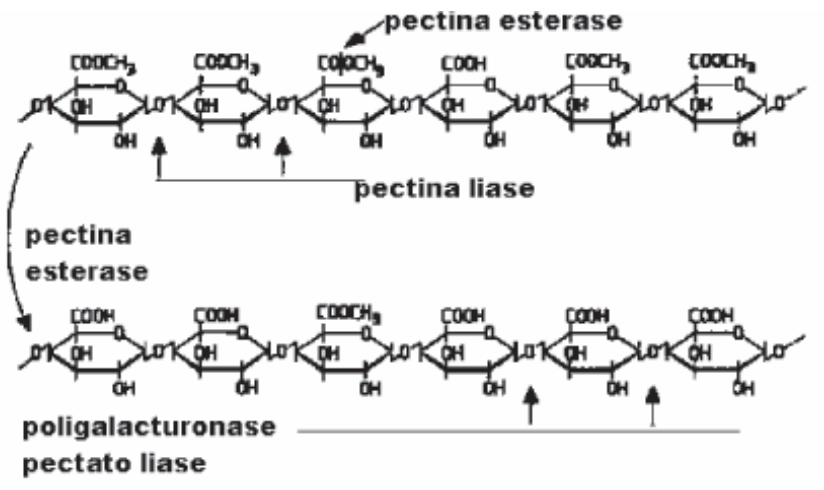

Figura 8. Estrutura da molécula de pectina e ação das enzimas pectinolíticas. Pectina esterase (PE) atua quebrando a ligação éster entre o grupo carboxila do ácido galacturônico e o grupo metila, liberando molécula desesterificada (ácido poligalacturônico); pectina liase (PL) atua despolimerizando a molécula de pectina por mecanismo de transeliminação do hidrogênio, inserindo dupla ligação entre os carbonos 4 e 5 do ácido galacturônico; poligalacturonase $(P G)$ catalisa a hidrólise da ligação glicosídica $\alpha, 1-4$ entre os ácidos galacturônicos. As liases e as hidrolases recebem a denominação pectina liase ou pectato liase e polimetilgalacturonase ou poligalacturonase quando atuam na pectina altamente esterificada ou no ácido poligalacturônico, respectivamente

despectinização simultânea à extração, usando pectinase termoestável, seria economicamente interessante ${ }^{115}$.

Uma vez que a pectina é um constituinte importante da parede celular vegetal, espera-se que essa enzima seja também comum entre os termófilos decompositores de polímeros vegetais. Exemplos de pectinases bacterianas termoestáveis constam da literatura, como as poligalacturonases alcalinas de Bacillus sp MG-cp-2, Bacillus sp DT7 e de Bacillus sp KSM-P7 ${ }^{114-117}$; a pectato liase de Thermoareobacter italicus $\mathrm{sp}$. nov ${ }^{118}$, a poligalacturonase de Clostridium thermosulfurogenes e a exopoligalacturonase de Thermotoga maritima ${ }^{119,120}$.

Poucos fungos termófilos pectinolíticos têm sido isolados ${ }^{17} \mathrm{e}$, da mesma forma, poucos dados são encontrados na literatura sobre a produção de pectinases por esse grupo fúngico. Inamdar ${ }^{17}$ estudou 40 fungos termófilos, dos quais apenas sete foram capazes de crescer em meio líquido contendo pectina. Desses, a maioria não mostrou atividade de poligalacturonase detectável no meio. Somente a espécie Thermoascus aurantiacus produziu quantidades consideráveis de pectinase em meio à base de casca de limão. A poligalacturonase produzida por esse fungo foi também estudada por Martins et al. ${ }^{121}$, a qual mostrou atividade ótima de $70{ }^{\circ} \mathrm{C}$ e estabilidade por $2 \mathrm{~h}$ a $60^{\circ} \mathrm{C}$.

Sathish-Kumar e Palanivelu ${ }^{122}$ relataram a produção de poligalacturonase por Thermomyces lanuginosus, cuja temperatura ótima atingiu $70{ }^{\circ} \mathrm{C}$ em sua forma bruta, a qual, após a purificação, apresentou temperatura ótima de $60{ }^{\circ} \mathrm{C}^{123}$. As pectinases produzidas por essa espécie ainda foram descritas por Purchart et al. ${ }^{124}$. Recentemente, Phutela et al. ${ }^{125}$ descreveram a produção de pectinases com atividade máxima a $60{ }^{\circ} \mathrm{C}$ pelo fungo termotolerante Aspergillus fumigatus.

\section{Xilanases termoestáveis}

As xilanases hidrolisam as moléculas de xilanas por mecanismos de ação endo e exo, conforme mostrado na Figura 9. Essas enzimas têm sido muito utilizadas na indústria papeleira, na etapa de branqueamento da polpa kraft. O biobranqueamento da polpa por xilanases, em substituição ao cloro, promove a remoção da xilana ligada ao complexo lignina-carboidrato facilitando a lixiviação da lignina. Por outro lado, o tratamento do material com xilanase na fase de pré-cozimento ajuda a desorganizar a estrutura da parede celular, facilitando, também, as etapas iniciais do processo ${ }^{3}$.

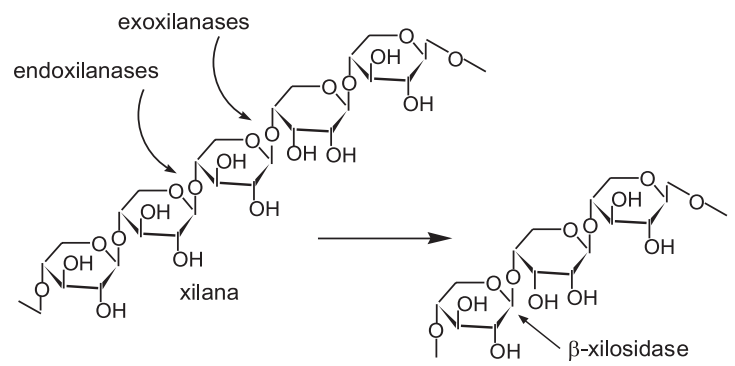

Figura 9. Estrutura da molécula de xilana e ação das xilanases. Endo- $\beta$ 1,4-xilanases hidrolisam as ligações glicosídicas $\beta, 1-4$ internas da moléculas de xilanas liberando xilooligossacarídeos, enquanto que as exo- $\beta$-xilanases liberam xilose a partir das extremidades não redutoras das xilanas; as $\beta$ xilosidases liberam xilose a partir da xilobiose ou xilooligossacarídeos curtos

Desde que a madeira usada para produção de polpa é tratada a altas temperaturas (acima de $70{ }^{\circ} \mathrm{C}$ ) e em pH alcalino, a etapa enzimática requer enzimas termoestáveis, com alta estabilidade e atividade em $\mathrm{pH}$ alcalino. Além disso, é necessário que o preparado enzimático seja livre de celulases, para evitar o ataque às fibras de celulose, tenha xilanases muito ativas, para reduzir o custo, e com baixo peso molecular, para facilitar sua difusão na polpa ${ }^{126-128}$.

As xilanases comerciais como as Pulpzyme e Cartazyme não são termoestáveis o suficiente (atividade ótima $50-60{ }^{\circ} \mathrm{C}$ e mantêm $50 \%$ de sua atividade por $15 \mathrm{~min}$ a $55^{\circ} \mathrm{C}$ ) para evitar a necessidade de um resfriamento da polpa após o tratamento alcalino ${ }^{44}$.

Inúmeros trabalhos têm relatado a produção de xilanases alcalinas e termoestáveis por organismos termófilos e hipertermófilos, procariotos e eucariotos. As atividades das xilanases termoestáveis descritas têm variado de 60 a $100{ }^{\circ} \mathrm{C}^{129-133}$.

Bactérias termofílicas, como Bacillus sp77-2, Bacillus amyloliquefaciens, Bacillus circulans, Streptomyces sp, Thermoactonomyces thalophilus sub grupo C e Thermotoga sp, têm se mostrado boas produtoras de xilanases termoestáveis, as quais atuam a $80{ }^{\circ} \mathrm{C}^{130,134-141}$. Entre os fungos, destacam-se o Thermoascus aurantiacus, Fusarium proliferatum, Thermomyces lanuginosus, Humicola insolens, Humicola lanuginosa, Paecilomyces variotim, Paecilomyces themophila, Scytalidium thermophilum, Melanocarpus albomyces e Chaetomium thermiphile com xilanases atuando entre 50 e $80{ }^{\circ} \mathrm{C}^{17,128,142-151}$. Thermomyces lanuginosus é conhecido por produzir altas concentrações de xilanase livre de celulase em fermentação submersa em meio com resíduos agrícolas como fontes de carbono ${ }^{18,124,145,152,153}$. Duas endoxilanases termoestáveis ativas e estáveis a $\mathrm{pH}$ alcalino produzidas fungo termófilo Myceliophthora sp. IMI 387099 foram descritas recentemente ${ }^{154}$.

Além do tratamento de polpa Kraft, as endoxilanases produzidas por Thermomyces lanuginosus e Thermoascus auranticus têm sido utilizadas no processamento de alimentos e nas indústrias de processamento do amido ${ }^{17}$.

Endo- $\beta$-xylanases com temperaturas ótimas de atividade em torno de $90{ }^{\circ} \mathrm{C}$ foram isoladas a partir de cultivo de hipertermofílicos Thermotoga sp, Thermotoga maritima, Thermotoga. neapolitana, Thermotoga themarum, Thermoanaerobacterium saccharolyticum e Sulfolobus solfataricus ${ }^{155-158}$.

\section{CONCLUSÕES}

Existe uma estreita relação entre o nicho ocupado por um microrganismo e as características de suas enzimas intra e extracelulares. 
Espera-se que microrganismos termófilos produzam enzimas extracelulares capazes de tolerar uma temperatura correspondente a, no mínimo, aquela ótima para seu crescimento, ou seja, acima de 45 ${ }^{\circ} \mathrm{C}$. Estudos com enzimas de termófilos têm mostrado que essa relação é verdadeira, estimulando o isolamento de novas linhagens termófilas, assim como a caracterização das enzimas produzidas e o entendimento dos fatores que levam a sua termoestabilidade.

Uma avaliação geral dos dados de literatura revela que ainda são necessários conhecimentos acerca da fisiologia dos organismos termofílicos com relação à composição química celular e aos mecanismos de ajustamento metabólico quando submetidos às temperaturas elevadas. A mais intrigante das questões é com relação à incapacidade dos fungos em crescer em temperaturas acima de $60{ }^{\circ} \mathrm{C}$. Ainda não são entendidas as diferenças entre a composição dos lipídios e de proteínas ligadas às membranas, a composição de suas cadeias respiratórias e a produção de energia, quando esses organismos crescem em condições mesofílicas e termofílicas.

Um dos mais significativos meios de adaptação à termofilia são os mecanismos intrínsecos, relacionados às estruturas primárias e secundárias das proteínas. Embora ainda não tenha sido estabelecido um padrão para termoestabilidade das proteínas, existem claras diferenças estruturais entre as proteínas de organismos mesófilos e aquelas de termófilos moderados e hipertermófilos. Por outro lado, considerandose a complexidade da estrutura de uma molécula de proteína é provável que não exista um mecanismo universal de termoestabilização.

A presente revisão aborda alguns aspectos importantes e já estabelecidos a respeito da termoestabilidade das proteínas e da adaptação bioquímica dos microrganismos a temperaturas acima da mesofílica, entretanto, fica evidente que o nível de conhecimento nessa área ainda não é suficiente para uma clara definição do perfil bioquímico/metabólico dos organismos termofílicos e muita pesquisa ainda é necessária para desenvolvimento de uma tecnologia de engenharia de proteínas para a obtenção de formas mais termoestáveis, visando uma aplicação biotecnológica.

A maior parte das informações aqui apresentada é referente a proteínas termoestáveis produzidas por organismos procariotos hipertermófilos os quais são, na sua maioria, do Domínio Achaea. Poucas dessas informações aplicam-se a organismos eucarióticos, visto que as características de termoestabilidade de fungos são pouco conhecidas. Em uma maior abrangência de informações sobre proteínas termoestáveis há que se considerar as diferenças filogenéticas entre os organismos produtores das mesmas. Assim, estudos comparativos entre mecanismos de termoesbilidade de microrganismos procariotos e eucariotos são ainda necessários.

\section{AGRADECIMENTOS}

À FAPESP e ao CNPq pelo apoio financeiro.

\section{REFERÊNCIAS}

1. Haki, G. D.; Rakshit, S. K.; Bioresour. Technol. 2003, 89, 17.

2. Colombatto, D.; Mould, F. L.; Bhat, M. K.; Phipps, R. H.; Owen, E.; Anim. Feed Sci. Technol. 2004, 111, 129.

3. Niehaus, F.; Bertoldo, C.; Kahler, C.; Antranikian, G.; Appl. Microbiol. Biotchenol. 1999, 51, 711.

4. Lasa, I.; Berenger, J.; Microbiology 1993, 9, 77.

5. Madigan, M. T.; Oren, A.; Curr. Opin. Microbiol. 1999, 2, 265.

6. Giulio, M. D.; J. Theor. Biol. 2000, 203, 203.

7. Arnold, F. H.; Wintrode, P. L.; Miyazaki, K.; Gershenson, A.; Trends Biochem. Sci. 2001, 26, 100.

8. Stetter, K. O.; FEMS Microbiol. Rev. 1996, 18, 149.

9. Adams, P. R.; Deployed, J. J.; Mycologia 1978, 70, 906.

10. Huber, R.; Langworthy, T. A.; König, H.; Thomm, M.; Woese, C. R.; Sleytr, U. B.; Stetter, K. O.; Arch. Microbiol. 1986, 144, 324.
11. Vieille, C.; Zeikus, G. J.; Microb. Mol. Biol. Rev. 2001, 65, 1.

12. Huber, R.; Eder, W.; Heldwein, S.; Wanner, G.; Hubr, H.; Rachel, R.; Stetter, K. O.; Appl. Environ. Microbiol. 1998, 64, 3576

13. Huber, R.; Wilharm, T.; Huber, D.; Trincone, A.; Burggraf, S.; König, H., Rachel, I.; Rockinger, I.; Fricke, H.; Stetter, K. O.; Syst. Appl. Microbiol. 1992, 25, 340

14. Huser, B. S.; Patel, B. K.; Daniel, R. M.; Morgan, H. W.; FEMS Microbiol. Lett. 1986, 37, 121.

15. Mouchacca, J.; Crypogram. Mycol. 1997, 18, 19

16. Chang, J. J., Tsai, J. J., Wu, K. H.; Bioresour. Technol., 2006, 97, 116

17. Maheshwari, R.; Bharadwaj, G.; Bath, M. K.; Microbiol. Mol. Biol. Rev. 2000, 64, 461

18. Singh, S.; Pillay, B.; Pror, A.; Enzyme Microb. Technol. 2000, 26, 502.

19. Adams, M. W. W.; Annu. Rev. Microbiol. 1993, 47, 627.

20. Jaenicke, R.; Böhm, G.; Curr. Opin. Struct. Biol. 1998, 8, 738.

21. Tolner, B.; Poolman, B.; Konings, W.N.; Comp. Biochem. Physiol., Part B: Biochem. Mol. Biol. 1997, 118A, 423.

22. De Rosa, M.; Morana, A.; Riccio, A.; Gambacorta, A., Trincone, A.; Incano, O.; Biosens. Bioelectron. 1994, 9, 669.

23. Jaenicke, R.; Eur. J. Biochem. 1991, 202, 715.

24. Lopes, G.; J. Mol. Evol. 1999, 46, 439.

25. Mandigam, M. T.; Martinko, J. M.; Parker, J.; BROCK Biology of Microorganisms, $10^{\text {th }}$ ed., Prentice Hall International Inc.: New York, 2003.

26. Thomas, T.; Caviocjioli, R.; FEBS Lett. 1998, 439, 281.

27. Singer, G. A. C.; Hickey, D. A.; Gene 2003, 317, 39.

28. Vieille, C.; Burdette, D. S.; Zeikus, J. G.; Biotechnol. Ann. Rev. 1996, 2, 1

29. Saraboji, K.; Grominha, M. M.; Ponuswany, M. N.; Int. J. Biol. Macromol. 2005, 35, 211.

30. Daniel, R. M.; Enzyme Microb. Technol. 1996, 19, 74.

31. Anfinsen, C. B.; Science 1973, 181, 223.

32. Jaenicke, R.; Prog. Biophys. Mol. Biol. 1999, 71, 155

33. Tomazic, S.; Libanov, A. M.; J. Biol. Chem. 1988, 263, 3086.

34. Demirijian, D.; Moris-Varas, F.; Cassidy, C.; Curr. Opin. Chem. Biol. 2001, $5,144$.

35. Lemos, C. M. Y.; Fuchs, E.; Gomes, E.; Da Silva, R.; Rev. Biotecnol. Desenvol. 2003, 31, 86.

36. Scandurra, R.; Consalvi, V.; Chiaraluce, R.; Politi, L.; Engel, P. C.; Biochimie 1998, 80, 933.

37. Kumar, S.; Nussinov, R.; Cell Mol. Life Sci. 2001, 58, 1216.

38. Voet, D.; Voet, J. G.; Pratt, C. W.; Fundamentos de Bioquímica, Ed. Artmed S.A.: Porto Alegre, 2002.

39. Fágáin, O. C.; Biochem. Biophys. Acta 1995, 1252, 1.

40. Shiraki, K.; Nishikori, S.; Fujiwara, S.; Hashimoto, H.; Kai, Y.; Takagi, M.; Imanaka, T.; Eur. J. Biochem. 2001, 268, 4144

41. Karshikoff, A.; Ladenstein, R.; Protein Eng. Des. Sel. 1998, 11, 867.

42. Pack, S. P.; Yoo, Y. J.; Int. J. Biol. Macromol. 2005, 35, 169.

43. Graziano, G.; Barone, G.; Catanzano, F.; Riccio, A.; Thermochim. Acta 1995, $270,381$.

44. Bruins, M.; Janssen, A. E. M.; Boom, R.; Appl. Biochem. Biotechnol. 2001, 90, 155.

45. Pack, S. P.; Yoo, Y. J.; J. Mol. Catal. B: Enzym. 2003, 26, 257.

46. Sziágy, A.; Závodszky, P.; Structure 2000, 8, 493

47. Vienen, M.; Protein Eng. 1987, 1, 477.

48. Kulakova, L.; Galkin, A.; Nakayama, T.; BBA- Prot. Proteom. 2004, 1696, 59.

49. Suzuki, Y.; Hatagaki, K.; Oda, H. A.; Appl. Microbiol. Biotechnol. 1991, 34, 707

50. Elcock, A. H.; J. Mol. Biol. 1998, 284, 489.

51. Mrabet, N. T.; van Den Brock, A.; van Den Brande, I.; Stanssens, P.; van Tilbeurgh, H.; Lambeir, A. M.; Mathijssens, J.; Janin, J.; Quax W. J.; Lasters, I.; De Meyer, M.; Wodak, S. J.; Biochemistry 1992, 31, 2239.

52. Matsumura, M.; Signor, M. G.; Matheus, B. W.; Nature 1989, 342, 291.

53. Dill, K. A.; Biochemistry 1990, 29, 7133.

54. Pace, C. N.; Shierley, B. A.; McNutt, M.; Gajiiwata, K.; FASEB J. 1996, 10, 7133 .

55. Vogt, G.; Woell, S.; Argos, P.; J. Mol. Biol. 1997, 258, 637.

56. Mustafa, B.; Buchnor, V.; Arad, D.; J. Mol. Biol. 1999, 254, 761.

57. Mozhaev, V. V.; Trends Biotechnol. 1992, 11, 88.

58. Lee, C-F.; Allen, M. D.; Bycroff, M.; Wong, K - B.; J. Mol. Biol. 2005, $248,419$.

59. Schmidt-Dannert, C.; Arnold, F. H.; Trends Biotechnol. 1999, 17, 135.

60. Madrich, L.; Merone, L.; Pezzullo, M.; Cipolla, L.; Nicotra, F.; Rossi, M.; Manco, G.; J. Mol. Biol. 2005, 345, 501.

61. Sajedi R. H.; Naderi-Manesh, H.; Khajeh, K.; Ahmadvand, R.; Ranjbar, B.; Asoodeh, A.; Moradian, F.; Enzyme Microb. Technol. 2005, 36, 666.

62. Bismuto, E.; Nucci, R.; Febbraio, F.; Eur. Biophys. J. 2004, 33, 39.

63. Stetter, K. O.; FEBS Lett. 1999, 452, 22. 
64. Wang, C.; Eufemi, M.; Turano, C.; Giartosio, A.; Biochemistry 1996, 35 7299.

65. Suthirak, P.; Dharmsthiti, S.; Lertsiri, S.; Process Biochem. 2005, 40, 2821 66. Muklhopadhyay, A.; Hagra, P. P.; Sengupta, T.; Biotechnol. Prog. 2003, 19, 700

67. Shima, S.; Thauer, R. K.; Ermler, U.; Biotechnol. Soc. Transac. 2004, 32, 269.

68. Honovitz, A.; Serrano, L.; Avron, B.; Bycroft, M.; Fersht, A. R.; J. Mol. Biol. 1998, 216, 1031.

69. Ellis, R. J.; Nature 1987, 328, 378.

70. Mayer, M. P.; Brechmer, D.; Gässler, C. S.; Bukau, B.; Adv. Protein Chem 2001, 59, 1 .

71. Wegele, H.; Müller, L.; Buchner, J.; Rev. Physiol. Biochem. Pharmacol 2004, 151, 1

72. Leuschner, C.; Antranikan, G.; World J. Microbiol. Biotechnol. 1995, 11, 95.

73. Palma-Fernandez, E. R.; Gomes, E.; Da Silva, R.; Folia Microbiol. 2002, 47, 685.

74. McCarthy, T.; Hanniffy, O.; Lalor, E.; Savage, A. V.; Yuohy, H. G.; Process Biochem. 2005, 40, 1742

75. Asghari, S. M.; Khajch, K.; Ranjbar, B.; Saedi, R. J. J.; Naderi-Manesh, H.; Int. J. Biol. Macromol. 2004, 34, 173.

76. Cowan, D. A.; Comp. Biochem. Physiol., Part B: Biochem. Mol. Biol. 1997, $118 A, 429$.

77. Teague, W. M.; Brumm, P. J. Em Starch Hydrolyzed Products; Schenk, F. W.; Hebeda, R. E, eds.; VCH Publishers: New York, 1992

78. Nigam, P.; Singh, D.; Enzyme Microb. Technol. 1995, 17, 770.

79. Adams, P. R.; Mycologia 1994, 128, 139.

80. Legin, E.; Ladrat, C.; Godfroy, A.; Barbier, G.; Duchiron, F.; C. R. Acad. Sci. 1997, 320, 893.

81. Specka, U.; Mayer, F.; Antranilian, G.; Appl. Environ. Microbiol. 1991, 57, 2317.

82. Hyun, H. H.; Zeikus, J. G.; Appl. Environ. Microbiol. 1985, 49, 1162.

83. Alves-Prado, H. F.; Hilário, E.; Gomes, E.; Da Silva, R.; Braz. J. Food Technol. 2002, 5, 189.

84. Bragger, J. M.; Daniel, R. M.; Coolbear, T.; Morgan, H. W.; Appl. Microbiol. Biotechnol. 1989, 31, 556.

85. Kim, Mi-S.; Park, J-T.; Kim, Y-W.; Lee, H-S.; Nywira, R.; Shim, H-S.; Park, C-S.; Yoo, S-H.; Kim, Y-R.; Moon, T-W.; Park, K-H.; Appl. Environ. Microbiol. 2004, 70, 3933.

86. Schumann, J.; Wrba, A.; Jaenike, R.; Stetter, K. O.; FEBS Lett. 1991, 282, 122

87. Chung, Y. C.; Kobayashi, T.; Kanai, H.; Akiba, T.; Kudo, T.; Appl. Environ. Microbiol. 1995, 61, 1502.

88. Brown, M. W.; Kelly, R. M.; Appl. Environ. Microbiol. 1993, 59, 2614.

89. Koch, R.; Spreinat, K.; Lemke, K.; Antranikian, G.; Arch. Microbiol. 1991, $155,572$.

90. Grzybowska, B.; Szweda, P.; Synoviecki, J.; Mol. Biotechnol. 2004, 26, 101

91. Hang, Y. D.; Woodams, E. E.; Lebensm. Wis. Technol. 1993, 26, 483.

92. Silva, W. B.; Peralta, R. M.; Can. J. Microbiol. 1998, 44, 493.

93. Mohapatra, B. R.; Banerjee, U. C.; Bapuji, M.; J. Biotechnol. 1998, 60, 113.

94. Yongsmith, B.; Kitprechacanich, V.; Chitradon, L.; Chaisrisook, C.; Bidda N.; J. Mol. Catal. B: Enzim. 2000, 10, 263

95. Marlida, Y.; Saari, N.; Hassan, Z.; Radu, S.; Bakar, J.; Food Chem. 2000 $71,221$.

96. Selvakumar, P.; Ashakumary, L.; Pandey, A.; Bioresour. Technol. 1998, 65, 83.

97. Jayachandran, S.; Ramabadran, R.; Indian J. Exp. Biol. 1970, 8, 344

98. Somkuti, G. A.; Steinberg, D. H.; Dev. Ind. Microbiol. 1980, 21, 327.

99. Aquino, A. C. M. M.; Jorge, J. A.; Terenzi, H. F.; Polizeli, M. L.; Appl. Microbiol. Biotechnol. 2003, 61, 323 .

100. Cereia, M.; Terenzi, H. F.; Jorge, J. A.; Greene, L. J.; Rosa, J.; Polizeli, M. L.; J. Basic. Microbiol. 2000, 40, 83.

101. Stamford, T. L. M.; Stamford, N. P.; Coelho, L. C. B. B.; Araújo, J. M.; Bioresour. Technol. 2002, 83, 105.

102. Nielsen, B. R.; Lehmbeck, J.; Frandsen, T.; Protein Expression. Purif. 2002, 26,1 .

103. Gomes, E.; Souza, S. R.; Picolo-Grandi, R.; Da Silva, R.; Braz. J. Microbiol. 2005, 36, 75 .

104. Campos, L.; Félix, C. R.; Appl. Environ. Microbiol. 1995, 61, 2436.

105. Taylor, P. M.; Napier, E. J.; Fleming, I. D.; Carbohydr. Res. 1978, 61, 301.

106. Arnesen, S.; Eriksen, S. H.; Olsen, J.; Jensen, B.; Enzyme Microb. Technol. 1998, 23, 249.

107. Rönazzéki, G.; Nguyem, Q. D.; Rezessy-Szabó, J. M.; Hoschke, Á.; Bhat, M. K.; Acta Alimenta 2000, 29, 71.

108. Nguyen, Q. D.; Rezessy-Szabó, J. M.; Claeyssens, M.; Stals, I.; Hoschke, Á.; Enzyme Microb. Technol. 2002, 31, 345.

109. Saha, B.; Zeikus, J. G.; Appl. Microbiol. Biotechnol. 1991, 35, 568.

110. Saha, B.; Zeikus, J. G.; Trends Biotechnol. 1989, 7, 243.

111. Tachibana, Y. A.; Kuramura, A.; Shirasaka, N.; Suzuki, Y.; Yamamoto, T; Fujiwara, S.; Takagi, M.; Imanaka, T.; Appl. Environ. Microbiol. 1999, 65, 1991

112. Lea, A. G. H. Em Enzymes in Food Processing; Tueker, G. A.; Woods, L. F. J., eds.; $2^{\text {nd }}$ ed, Backie Academic \& Professional: Glasgow, 1998.
113. Kaur, G.; Kumar, S.; Satyanarayana, T.; Bioresour. Technol. 2004, 94, 239.

114. Kapoor, M.; Geg, Q. K.; Bhushan, B.; Dadhich, K. S.; Hoondal, G. S.; Process Biochem. 2000, 36, 467.

115. Singh, S. A.; Plattner, H.; Diekman, H.; Enzyme Microbiol. Technol. 1999, 25,420 .

116. Kashyap, D. R.; Soni, S. K.; Tewari, R.; Bioresour. Technol. 2003, 88, 251.

117. Kobayashi, T.; Hatada, Y.; Higaki, N.; Lusterio, D. D.; Ozawa, T.; Koike, K.; Kawai, S.; Ito, S.; Biochim. Biophys. Acta 1999, 1427, 145.

118. Kozianowski, G.; Canganella, F.; Rainey, F. A.; Hippe, H.; Antranikian, G.; Extremophiles 1997, 1, 171.

119. Parisot, J.; Langlois, V.; Sakamyan, V.; Carbohydr. Res. 2003, 338, 1333.

120. Schink, B.; Zeikus, J. G.; FEMS Microbiol. Lett. 1983, 17, 295.

121. Martins, E. S.; Silva, D.; Da Silva, R.; Gomes, E.; Process Biochem. 2002, 37, 949.

122. Sathish-Kumar, S.; Palanivelu, P.; World. J. Microbiol. Biotechnol. 1998, 14,781 .

123. Sathish-Kumar, S.; Palanivelu, P.; World. J. Microbiol. Biotechnol. 1999, 15,643 .

124. Puchart, V.; Katapodis, P.; Biely, P.; Kremnický, A.; Bhat, M. K.; Enzyme Microbiol. Technol. 1999, 24, 355.

125. Phutela, U.; Dhuna, V.; Sandhu, S.; Chadha, B. S.; Braz. J. Microbiol. 2005, 36,63 .

126. Tchapun, C.; Poosaram, N.; Watanabe, M.; Process Biochem. 2003, 38, 1327.

127. Harris, G. W.; Pickersgill, W.; Connerton, I.; Debeire, P.; Touzel, J. P.; Breton, C.; Perez, S.; Proteins 1997, 29, 77.

128. Anand, L.; Krishnamurty, S.; Vithayathil, P. J.; Arch. Biochem. Biophys. 1990, $276,546$.

129. Palackal, N.; Brennan, Y.; Callen, W. N.; Dupree, P.; Frey, G.; Goubet, F.; Steer, B. A.; Protein Sci. 2004, 13, 494

130. Kohilu, U.; Nigam, P.; Singh, D.; Chaudhary, K.; Enzyme Microb. Technol. 2001, 28, 606.

131. Marjaana, R.; Indra, M.; Birgitte, A.; Liisa, V.; Appl. Microbiol. Biotechnol. 1994, 41, 130.

132. Ruthersmith, L.; Daniel, R.; Ann. N. Y. Acad. Sci. 1992, 672, 137.

133. Medda, S.; Chandra, K.; J. Appl. Bacteriol. 1980, 48, 47.

134. Dhillon, A.; Khama, S.; World J. Microbiol. Biotechnol. 2000, $27,144$.

135. Breccia, J.; Sineriz, F.; Baigoni, M. D.; Guillermo, R. C.; Hatti - Kaul, R.; Enzyme Microb. Technol. 1997, 22, 420.

136. Simpson, H.; Haufler, U.; Daniel, K.; Biochem. J. 1991, 277, 177.

137. Bocchini, D. A.; Alves-Prado, H. F.; Baida, L. C.; Roberto, I. C.; Gomes, E.; Da Silva, R.; Process Biochem. 2002, 38, 727

138. Bocchini, D. A.; Damiano, V. B.; Gomes, E.; Da Silva, R.; Appl. Biochem. Biotechnol. 2003, 39, 393

139. Tavares, V. B.; Gomes, E.; Da Silva R.; Rev. Microbiol. 1997, 28, 179.

140. Damiano, V. B.; Bocchini, D. A.; Gomes, E.; Da Silva, R.; World J. Microbiol. Biotechnol. 2003, 19, 139.

141. Bocchini, D. A.; Oliveira, O. M. M. F. B.; Gomes, E., Da Silva, R.; Process Biochem. 2005, 40, 3653.

142. Damaso, M. C. T.; Andrade, F. M. C.; Pereira, N.; Braz. J. Microbiol. 2003, $33,333$.

143. Badal, C.; Process Biochem. 2002, 37, 1279

144. Kalogeris, E.; Christalkopoulos, D.; Kekos, D.; Macris, B. J.; J. Biotechnol. 1998, 60, 155

145. Gomes, J.; Gomes, I.; Kreiner, W.; Esterbauer, H.; Sinner, M.; Steiner, W.; J. Biotechnol. 1993, 30, 283.

146. Khandke, K.; Vithayathil, P. J.; Murthy, S. K.; Arch. Biochem. Biophys. 1989, 274, 491 .

147. Tan, L. U. L.; Mayers, P.; Saddler, J. N.; Can. J. Microbiol. 1987, 33, 689.

148. Li, X. T.; Jiang, Z. Q.; Li, L. T.; Yang, S. Q.; Feng, W. Y.; Fan, J. Y.; Kusakabe, I.; Bioresour. Technol. 2005, 96, 1379.

149. Li, L.; Tian, H.; Cheng, Y.; Jiamg, Z.; Yang, S.; Enzyme Microb. Technol. 2005, 38, 780

150. Gonju, R. K.; Vithayathil, P. J.; Murthy, S. K.; Can. J. Microbiol. 1989 35,836

151. Düsterhöft, E. M.; Linssen, V. A. J. M.; Voragen, A. G. J.; Beldman, G.; Enzyme Microb. Technol. 1997, 20, 437.

152. Purkarthofer, H. M.; Sinner, M.; Steiner, W.; Biotechnol. Lett. 1993, 15, 405.

153. Sonia, K. G.; Chadha, B. S.; Saini, H. S.; Bioresour. Technol. 2005, 96, 1561.

154. Chadha, B. S.; Ajay, B. K.; Mellon, F.; Bhat, M. K.; J. Biotechnol. 2004, 109, 221.

155. Cannio, R.; Di Prizito, N.; Rossi, M.; Extremophiles 2004, 8, 117.

156. Saul, D.; Williams, L.; Reeves, R.; Gibbs, M.; Bergquist, P.; Appl. Environ. Microb. 1995, 61, 4110.

157. Wintherhalter, C.; Liegh, W.; Appl. Environ. Microbiol. 1995, 61, 1810.

158. Lee, Y. E.; Lowe, S. E.; Henrissat, B.; Zeikus, J. G.; J. Bacteriol. 1993, 175, 5890 . 